\title{
Metal contamination budget at the river basin scale: an original Flux-Flow Analysis (F2A) for the Seine River
}

\author{
L. Lestel ${ }^{1}$, M. Meybeck ${ }^{2}$, and D. R. Thévenot ${ }^{3}$ \\ ${ }^{1}$ Centre d'Histoire des Techniques et de l'Environnement, CNAM, case I-161, 5 rue du Vertbois, 75003 Paris, France \\ ${ }^{2}$ UMR Sisyphe 7619, Université P. et M. Curie, boite 105, 4 place Jussieu, 75006 Paris, France \\ ${ }^{3}$ Centre d'Enseignement et de Recherche sur l'Eau, la Ville et l'Environnement (Cereve), UMR-MA 102, Université Paris 12 \\ Val de Marne, Faculté de Sciences et Technologie, 61 Avenue du Général de Gaulle, 94010 Créteil Cedex, France
}

Received: 23 May 2007 - Published in Hydrol. Earth Syst. Sci. Discuss.: 20 June 2007

Revised: 12 October 2007 - Accepted: 25 October 2007 - Published: 16 November 2007

\begin{abstract}
Material flow analysis and environmental contamination analysis are merged into a Flux-Flow analysis (F2A) as illustrated for the metal circulation in the Seine River catchment. F2A combines about 30 metal flows in the anthroposphere (14 million people) and/or metal fluxes in the environment (atmosphere, soils, and aquatic system) originating from two dozens of sources. The nature and quality of data is very heterogeneous going from downscaled national economic statistics to upscaled daily environmental surveys.

A triple integration is performed: space integration over the catchment $\left(65000 \mathrm{~km}^{2}\right)$, time integration for the 1950 2000 trend analysed at 5 year resolution, and a conceptual integration resulting in two F2A indicators.

Despite the various data sources an average metal circulation is established for the 1994-2003 period and illustrated for zinc: (i) metal circulation in the anthroposphere is now two orders of magnitude higher than river outputs, (ii) long term metal storage, and their potential leaks, in soils, wastedumps and structures is also orders of magnitude higher than present river fluxes. Trend analysis is made through two F2A indicators, the per capita excess load at the river outlet and the leakage ratio (excess fluxes/metal demand). From 1950 to 2000 , they both show a ten fold improvement of metal recycling while the metal demand has increased by 2.5 to 5 for $\mathrm{Cd}, \mathrm{Cu}, \mathrm{Cr}, \mathrm{Pb}$ and $\mathrm{Zn}$, and the population by $50 \%$.
\end{abstract}

\section{Introduction}

Transfers of contaminants on a given territory are generally studied by different communities considering either the material flow analysis (MFA) (Baccini and Brunner, 1991; Brunner and Rechberger, 2004; Graedel and Allendy, 2003;

Correspondence to: L. Lestel

(lestel@cnam.fr)
Stigliani et al., 1993) or the environmental contamination analysis (ECA) (Trefry et al., 1986; Horowitz, 1991; Winkels et al., 1998; Grousset et al., 1999; Zwolsman and van Eck, 1999; Cave et al., 2003). Both communities are using different approaches and concepts, their time and space scales may be different and they rarely share identical indicators.

From an environmental point of view, particularly for river catchment contamination, analyses are often focused on pollutants fluxes and fate (e.g. river fluxes, atmospheric inputs); the transfers occurring within the anthroposphere are not addressed and only considered through potential leaks (Salomons and Forstner, 1984). On the other hand, classical MFA focuses on imports, exports, usage of goods, their transformation and recycling.

MFA is often made for administrative spatial units such as cities (Stockholm, Bergbäck et al., 2001), counties, and countries (Belgium, Billen et al., 1983) for which economic statistics are available. They also have their own time steps, annual to pluriannual, and their data uncertainty is often unknown. ECA is performed on entities with natural boundaries such as river basins for which output fluxes can be determined, providing natural space integration. Some ECA are also made at very fine spatial (e.g. rain gauges, lysimeters) and temporal (subdaily) scales. Long term trends on economic data $(>20 \mathrm{y})$ are more common than those available from environmental surveys.

We are trying here to combine both MFA and ECA approaches into an original Flux-Flow Analysis (F2A) in a single study of metal contamination in the Seine River catchment. Here Fluxes refer to transfers between natural reservoirs (atmosphere, pedosphere, hydrosphere, etc. ) while Flows refer to transfers within the anthroposphere, generally controlled by human activities (material, goods, wastes). A similar approach has already been used in some nitrogen and phosphorus budgets in river basins which greatly depends on nutrients flows (e.g. P-detergents, $\mathrm{N}$-fertilizers), although not

Published by Copernicus Publications on behalf of the European Geosciences Union. 


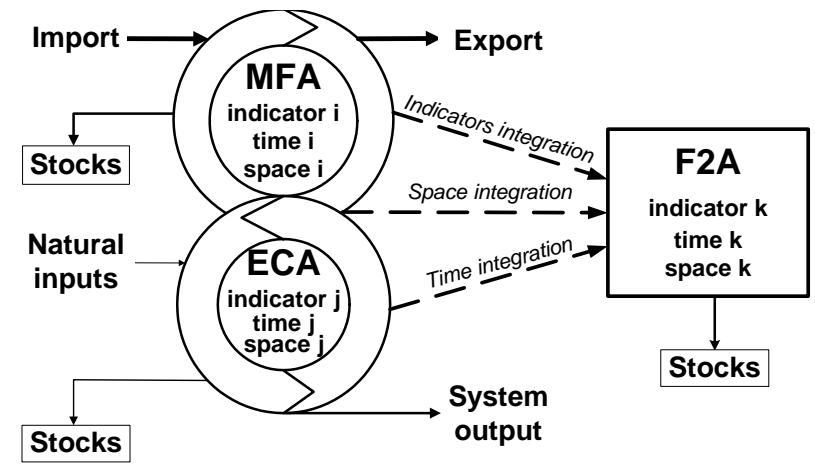

Fig. 1. The triple integration of material Flow/contaminant Fluxes analysis (F2A).

detailed (Billen et al., 2007). Metals have been chosen because their use history is relatively well documented, and their contamination trends can be reconstructed over a period of $50 \mathrm{yrs}$ from sediment archives. The Seine River catchment is selected for multiple reasons: (i) its size $\left(65000 \mathrm{~km}^{2}\right)$ and multiple economic activities make it very representative of the post-war II evolution of western Europe catchments, (ii) its economic drivers and human pressures on the environment can be determined from national and local statistics, (iii) the environmental circulation of metals has been described in many papers published by the PIREN Seine program and recently synthesized by Thévenot et al. (2007) and Meybeck et al. (2007). The catchment is characterized by a very high population density (average 215 people $\mathrm{km}^{-2}$ ) essentially aggregated in Paris conurbation $\left(2,740 \mathrm{~km}^{2}, 9.47 \mathrm{M}\right.$ inhabitants, 415 municipalities), which is further mentioned as Paris megacity.

In this paper, we are presenting first our conceptual integration of MFA and ECA, termed here F2A (Fluxes-Flows analysis), then a critical analysis of our data base. The integrated budget of zinc for the period 1994-2003 is discussed. Finally, the long term circulation (1950-2000) of metals in the system is analysed through two integrated indicators.

\section{The F2A methodology (Fluxes-Flows Analysis)}

Both MFA and ECA are characterized by inputs/outputs fluxes (generally in $\mathrm{ty}^{-1}$ ) and by stocks of material in constructions, goods, dumps and in soils and sediments (generally expressed in $\mathrm{t}$ ).

The F2A can be conceived as a triple integration (Fig. 1): (i) first a spatial integration, merging the spatial limits of both MFA and ECA: we believe that it is easier to constrain MFA boundaries to natural boundaries, such as river catchment, than the opposite, (ii) then a temporal integration, using the same budget periods and time steps for all kinds of indicators either economics (indicators i) or environmental (indicators j), (iii) finally a conceptual integration resulting in F2A in- dicators (indicators $\mathrm{k}$ ) defined for the selected temporal and spatial scales. This approach has a great similarity to the one established by Billen et al. (1983) for the matter circulation in Belgium and by Ciais et al. (2006) for the carbon fluxes in Western Europe. The consideration of a river catchment allows for an easier estimate of present excess load and the reconstruction of their past trajectories through environmental archives.

In its present stage, the F2A analysis on a river catchment is mixing five different types of information (Tables 1-3 and Fig. 2): (i) circulation of metal products and goods (flows P1 to P10), (ii) leaks from the anthroposhere to the environment (L1 to L7), (iii) transfers of metal in the atmosphere and into the river system (T1 to T4), (iv) anthropogenic storage of metals on the catchment (SA, SF, SI, SL, SU) and storage of metal-containing sediments along the river course, from lakes and reservoirs to the estuary (storages from river $\mathrm{SR}_{1}$ to $\mathrm{SR}_{3}$ ), (v) contamination records obtained from sediment archives (A1 to A3). The floodplain cores in the lower course of the river (A2) are used to reconstruct the metal contamination over 65 yrs (Meybeck et al., 2007).

Since it is very difficult to obtain all the necessary information at the same time, i.e. for a given year, we have considered an average metal budget for a period of $10 \mathrm{yrs}$, assuming that most fluxes and flows determined over shorter periods (e.g. sewage budgets; fertilizer uses; atmospheric fallout) are constant and/or can be averaged. Sewage collection (e.g. $\left.\mathrm{L} 3_{\mathrm{A}, \mathrm{B}}\right)$, treatment and reuse $\left(\mathrm{P} 8_{\mathrm{B}}\right)$, release $(\mathrm{L} 4)$ and the river sediment dredging (P10), that are controlled by human activities, are considered as flows while the street runoff (L6) is considered as a transfer between natural reservoirs and thus as a flux.

Two indicators illustrating the long-term evolution of metal circulation have been generated from the fluxes-flows analysis (F2A): the per capita excess loads of metals and the leakage ratio. They describe the evolution of metal circulation over a period of $50 \mathrm{yrs:}$ (i) the per capita excess load of metals corresponds to the estimated metal surplus in river material that escapes the river system, expressed as g metal per capita per year, (ii) the leakage ratio over the river catchment is the ratio of excess metal flux at the river outlet divided by the general metal use in the catchment (Meybeck et al., 2007). Both indicators are averaged over periods of $5 \mathrm{yrs}$ that smoothes the year to year variations of metal uses and of the riverine fluxes.

\section{Characterization and critical analysis of data sources}

The construction of this metal budget implied the use of heterogeneous data from multiple sources, which are first presented. Many of them had to be upscaled/downscaled spatially or temporally in order to allow their integration in our conceptual model. This will be discussed in the second subsection. Finally the limitations of each type of data were 


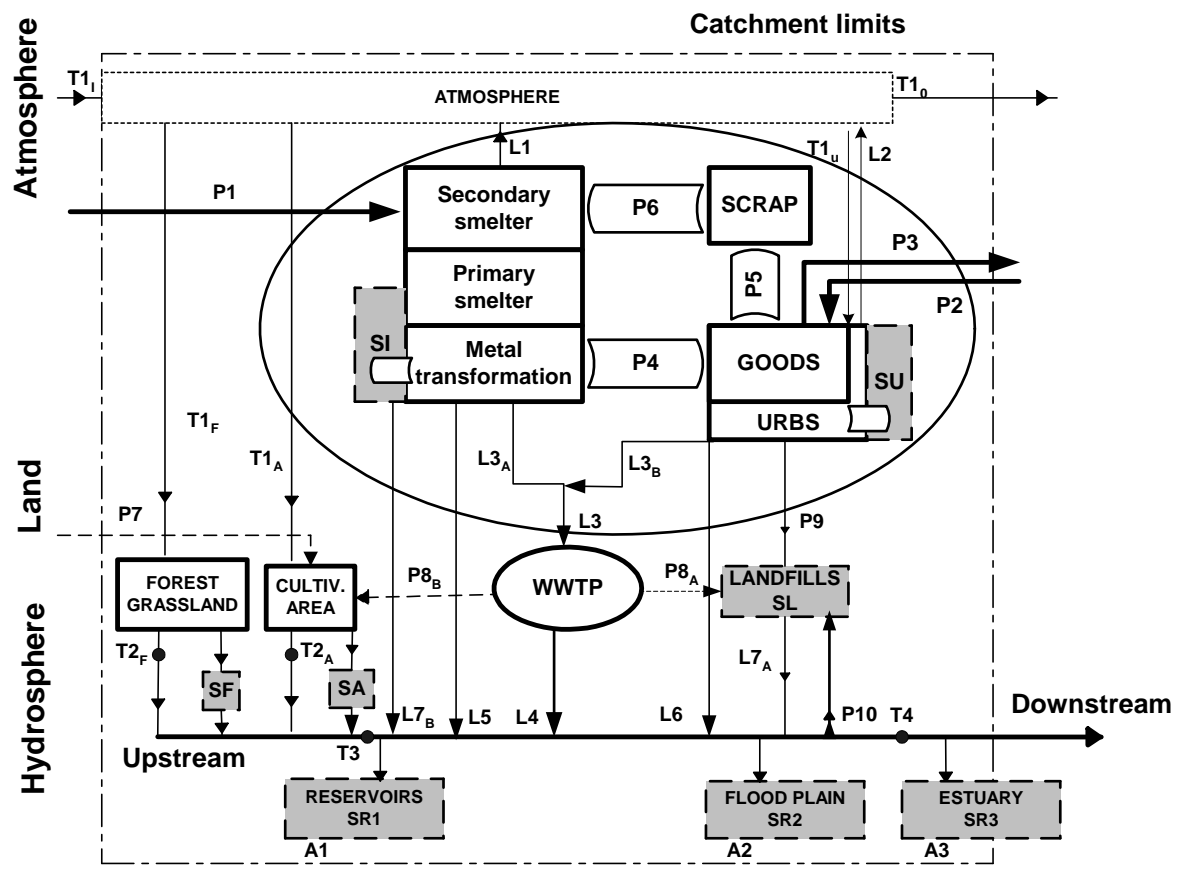

Fig. 2. Schematic sources, transfers, sinks of metals in a river catchment combined with metal uses, recycling and leaks in the anthroposphere. P1 to P10: circulation of metal products and goods. L1 to L7: leaks from the anthroposphere to the environment. T1 to T4: transfers. SA to SU: storage. A: sediment archives of past river contamination.

Grey area: metal storage sites. •: River stations. (WWTP): waste water treatment plants (see also Tables 1, 2, 3).

analysed through various criteria: data quality control, space adequation, temporal adequation and data accessibility.

\subsection{Data collection}

More than 30 different sources of data have been used to assess the drivers of metal uses and their related pressures and the state of the environment (Tables 1, 2, 3). Primary sources originate from diverse public providers, including five different ministries, the French National Statistic Institution (INSEE), specific institutions such the $\mathrm{Na}$ tional Environmental Agency (ADEME), the Seine River Basin Authority (AESN), Paris megacity Sanitation Institution (SIAAP), the Seine River Navigation Authority (SNS), the technical assistance service (SATESE) to wastewater treatment plants (WWTP), the national atmospheric emission agency (CITEPA). The non ferrous metal industries yearbooks are our main data source from the private sector (FEDEM, 2003). For the Environmental state, academic studies (most of them generated by the PIREN Seine program, Azimi et al., 2003; Azimi et al., 2005; Garnaud et al., 1999; Gromaire et al., 2002; Grosbois et al., 2006; Meybeck et al., 2007; Thévenot et al., 2007) were used, along with river survey data at the River basin scale from the River Basin Authority and data arising from European programs (such as the Corine Land Cover from the European Environmental Agency, EEA, 2000), and some data coming from ministries.
Many data for metal circulation of goods result from the combination of several primary sources: for example, lead contained in TV screens (P4a, Table 4) is known from the amount of lead in a cathodic tube then multiplied by the number of TV sets estimated in the Seine river basin. Cadmium inputs to crops from $\mathrm{P}$ fertilisers are calculated from fertiliser use statistics (Unifa, 2005) and their average $\mathrm{Cd} / \mathrm{P}$ ratio. Despite the diversity of sources, some data are still missing such as metal stocks which remain mostly unknown.

Some metal flows are estimated by different agencies using different approaches. This is illustrated for leadtetraethyl use and/or emission to the atmosphere $\left(\mathrm{P} 4_{d}\right.$, Table 4 and Fig. 3) and for the metal contents in industrial waste waters which can be estimated from (i) nominal rates based on industrial production, (ii) auto controls reported by industries (EauFrance, 2004; IREP, 2004) and (iii) from external controls without notice made by assistance services (SATESE) at random dates.

Aggregated statistics on usages of goods are commonly found in economical statistics. Yet the environmental behavior of these products is often very different: e.g. lead pigments and explosives are combined as "chemicals". The metal content of many goods and wastes is often not monitored and may greatly vary over time (cadmium in batteries, mercury in dental care). Until recently, the only available metal emissions to the river were aggregated by water 
Table 1. Major data sources of metal flows (Pi) for material flow analysis (MFA), (see also Fig. 2).

\begin{tabular}{|c|c|c|c|c|}
\hline & Type of flows & Data sources & $\begin{array}{l}\text { Start of } \\
\text { record }\end{array}$ & Data provider \\
\hline $\mathrm{P} 1$ & Import of ores and ingots & Mines yearbook & $<1847$ & Ministry of Industries \\
\hline $\mathrm{P} 2$ & Import of Me-containing goods & $\begin{array}{l}\text { Yearbooks of imported/ } \\
\text { exported goods }\end{array}$ & $>1950$ & Ministry of Finances (customs) \\
\hline P3 & Export of Me-containing goods & $\begin{array}{l}\text { Yearbooks of imported/ } \\
\text { exported goods }\end{array}$ & $>1950$ & Ministry of Finances (customs) \\
\hline P4 & Metal demand & $\begin{array}{l}\text { Mines yearbook; } \\
\text { Non-ferrous ores and metal } \\
\text { yearbook }\end{array}$ & 1816 & $\begin{array}{l}\text { Ministry of Agriculture, Industry and } \\
\text { Public Works (19th century) and national } \\
\text { federation of Non-ferrous metal industries } \\
\text { (20th century) }\end{array}$ \\
\hline $\mathrm{P} 4 \mathrm{a}, \mathrm{d}$ & Metal containing goods & & & $\begin{array}{l}\text { Calculated from miscellaneous } \\
\text { (generally economical) sources (see text) }\end{array}$ \\
\hline P5 & Collection of metals for recycling & Spots estimates & 1990’s & $\begin{array}{lll}\text { National } & \text { Environmental } & \text { Agency } \\
\text { (ADEME) } & & \end{array}$ \\
\hline P6 & Recycling (scrap industry) & $\begin{array}{l}\text { Non-ferrous ores and metal } \\
\text { yearbook }\end{array}$ & 1940’s & $\begin{array}{l}\text { Non-ferrous metal industries national } \\
\text { federation }\end{array}$ \\
\hline P7 & $\begin{array}{l}\text { Metal-containing fertiliser inputs } \\
\text { to soils }\end{array}$ & $\begin{array}{l}\text { Land use/cover } \times \text { fertilizer } \\
\text { use }\end{array}$ & 1980’s & $\begin{array}{l}\text { EU Corine Land Cover, Ministry of Agri- } \\
\text { culture }\end{array}$ \\
\hline $\mathrm{P}_{B}$ & Reuse of treated urban sludges & $\begin{array}{l}\text { Direct survey before/after } \\
\text { treatment } \times \text { reuse statistics }\end{array}$ & 1977 & $\begin{array}{l}\text { Paris megacity sanitary institution } \\
\text { (SIAAP) }\end{array}$ \\
\hline P9 & $\begin{array}{l}\text { Collection and incineration of } \\
\text { municipal and industrial solid } \\
\text { wastes }\end{array}$ & $\begin{array}{l}\text { Annual collection rate } \mathrm{x} \text { es- } \\
\text { timated metal content }\end{array}$ & 1980’s & ADEME \\
\hline P10 & Dredged river material & $\begin{array}{l}\text { Direct survey of sediments } \\
\text { before the dredging opera- } \\
\text { tion } \times \text { dredging statistics }\end{array}$ & 1990’s & Seine River navigation Authority (SNS) \\
\hline
\end{tabular}

Table 2. Major data sources for environmental contamination analysis (ECA) (transfers Tj) (Fig. 2).

\begin{tabular}{|c|c|c|c|c|}
\hline & Fluxes & Type of data & $\begin{array}{l}\text { Start of } \\
\text { record }\end{array}$ & Data provider \\
\hline $\mathrm{T} 1$ & $\begin{array}{l}\text { Atmospheric fallout on } \\
\text { forest }\left(\mathrm{T} 1_{\mathrm{F}}\right) \text {, cultivated } \\
\text { areas }\left(\mathrm{T} 1_{\mathrm{A}}\right) \text { and urban } \\
\text { areas }\left(\mathrm{T} 1_{\mathrm{U}}\right)\end{array}$ & $\begin{array}{l}\text { Daily to monthly fallout survey at } \\
\text { selected sites }\end{array}$ & 1994 & $\begin{array}{l}\text { Academic publications } \\
\text { (Azimi et al., } 2003 \text { and 2005) }\end{array}$ \\
\hline $\mathrm{T} 2$ & $\begin{array}{l}\text { Outputs from forested }\left(\mathrm{T} 2_{\mathrm{F}}\right) \text { and } \\
\text { agricultural }\left(\mathrm{T} 2_{\mathrm{A}}\right) \text { catchments }\end{array}$ & $\begin{array}{l}\text { Direct metal analysis of river sed- } \\
\text { iment from forested and agricul- } \\
\text { tural stream } \\
\text { catchments } \times \text { erosion rates }\end{array}$ & & $\begin{array}{l}\text { Academic publications } \\
\text { (Grosbois et al., 2006) }\end{array}$ \\
\hline $\mathrm{T} 3$ & Natural river fluxes & $\begin{array}{l}\text { Pristine headwaters } \\
\text { inventories; sediment archives }\end{array}$ & 1994 & $\begin{array}{l}\text { Academic publications } \\
\text { (Grosbois et al., 2006) }\end{array}$ \\
\hline $\mathrm{T} 4$ & River basin output & $\begin{array}{l}\text { River mouth survey } \\
\text { (RNB national network) }\end{array}$ & 1983 & $\begin{array}{l}\text { Seine Basin Authority; Ministry of } \\
\text { Environment (DIREN de Bassin); } \\
\text { Academic studies }\end{array}$ \\
\hline
\end{tabular}

authorities (Agences de l'eau) through the METOX load, a basket of six metals weighted according to their respective toxicity, assessed from industrial production data: this aggregated indicator is obviously unusable for MFA, where data specific for each metal are required.

\subsection{Upscaling/downscaling}

Data have been collected at multiple spatial scales from $10 \mathrm{~m}^{2}$ (agricultural plots) to $550000 \mathrm{~km}^{2}$ (national statistics). Since the Seine catchment area is $65000 \mathrm{~km}^{2}$, they had to be either downscaled or upscaled: 
Table 3. Data sources for metal leaks to the environment (Li, Lj, see Fig. 2).

\begin{tabular}{|c|c|c|c|c|}
\hline & Leaks & Type of data & $\begin{array}{l}\text { Start of } \\
\text { record }\end{array}$ & Data provider \\
\hline L1, L2 & $\begin{array}{l}\text { Atmospheric metal } \\
\text { emissions }\end{array}$ & $\begin{array}{l}\text { Specific register of } \\
\text { atmospheric emissions } \\
\text { (metal section) }\end{array}$ & 1990 & $\begin{array}{l}\text { CITEPA founded by the Ministry of } \\
\text { Environment }\end{array}$ \\
\hline L1 & $\begin{array}{l}\text { Industrial atmospheric } \\
\text { emission }\end{array}$ & $\begin{array}{l}\text { European pollutants } \\
\text { emission register }\end{array}$ & 2001 & EPER, European Environmental Agency \\
\hline L4 & $\begin{array}{l}\text { Release of treated } \\
\text { wastewater to the river }\end{array}$ & $\begin{array}{l}\text { Monthly to weekly } \\
\text { surveys } \times \text { water budgets }\end{array}$ & 1977 & $\begin{array}{l}\text { Paris megacity Sanitation Institution } \\
\text { (SIAAP) }\end{array}$ \\
\hline $\mathrm{L} 3_{\mathrm{A}}, \mathrm{L} 5^{(1)}$ & $\begin{array}{l}\text { Nominal industrial waste } \\
\text { water } \\
\text { production }\end{array}$ & Pollution tax register & 1980’s & Seine Basin Authority AESN \\
\hline $\mathrm{L} 3_{\mathrm{A}}, \mathrm{L} 5^{(1)}$ & $\begin{array}{l}\text { Industrial waste water } \\
\text { production }\end{array}$ & Auto control & 1980 ’s & Seine Basin Authority AESN \\
\hline $\mathrm{L} 3_{\mathrm{A}}, \mathrm{L} 5^{(1)}$ & $\begin{array}{l}\text { Industrial waste water } \\
\text { production }\end{array}$ & $\begin{array}{l}\text { Voluntary industrial decla- } \\
\text { ration procedure }\end{array}$ & 2000’s & $\begin{array}{l}\text { Ministry of Environment (IREP national } \\
\text { register) }\end{array}$ \\
\hline $\mathrm{L} 3{ }_{\mathrm{A}}, \mathrm{L} 5^{(1)}$ & $\begin{array}{l}\text { Industrial waste water } \\
\text { production }\end{array}$ & $\begin{array}{l}\text { External control without } \\
\text { notice }\end{array}$ & 1990’s & $\begin{array}{l}\text { SATESE (Technical assistance service to } \\
\text { sewage treatment plants) }\end{array}$ \\
\hline L6 & Metal in urban wastes & $\begin{array}{l}\text { Direct surveys of untreated } \\
\text { wastes and sludges }\end{array}$ & 1977 & $\begin{array}{l}\text { Paris megacity Sanitation Institution } \\
\text { (SIAAP) }\end{array}$ \\
\hline
\end{tabular}

(1) the leaks from industry to the river system (L3 A and L5) are calculated or measured by different ways.

1. Downscaling socioeconomic data. Many economic activity data are only available at the country scale. They were downscaled here proportionally to Seine river basin (i) population (14/60 million inhabitants in 2000), (ii) industrial activity (typically $30 \%$ according to specific industrial inventories), and (iii) agricultural production (e.g. $20 \%$ for the oleaginous plants and for cereals).

2. Upscaling socioeconomic data. Few economic data are generated at the county scale ("département" in French, typically $5000 \mathrm{~km}^{2}$ ), such as the atmospheric emissions, or at the municipal scale (typically $20 \mathrm{~km}^{2}$ ), such as the population. These data have been scaled proportionnaly to their area within the catchment limits.

3. Upscaling environmental data. (i) Agricultural plots $\left(10 \mathrm{~m}^{2}\right)$ were used to assess metal circulations in agrochemicals, soils, water and crops and were upscaled proportionally to land use and land cover data derived from satellite (Corinne Land Cover) and from agricultural census. (ii) A pilot study on an urban sewage basin $\left(0.4 \mathrm{~km}^{2}\right)$ was used to asses metal circulation in Paris megacity from atmospheric fallout, roof and street runoff, and domestic sources (Thévenot et al., 2007). It was upscaled proportionally to Paris megacity land cover and to population according to population census. (iii) Sewage inputs have to be upscaled using data related to the large waste water treatment plant (WWTP) of Paris megacity (Seine-Aval WWTP), at which 8 mil- lion inhabitants were connected; these pressures were then upscaled to the whole catchment using the population ratio. (iv) Small forested river basins (10 to $100 \mathrm{~km}^{2}$ ) were used to assess natural geochemical background of metals. (v) River surveys at stations upstream $\left(10000 \mathrm{~km}^{2}\right)$ and downstream of Paris provided data for the Paris megacity impact (total area: $2740 \mathrm{~km}^{2}$ ).

4. Extrapolating metal contamination inventories. Only very few data pertinent to the metal contamination are collected and archived at the river basin scale, as domestic and industrial sewage inputs. However these data sets are not comprehensive and have variable data quality control. A new register of point sources inputs is currently realised (AESN, 2006) as a consequence of the Water Framework Directive application but could not be used here in a retrospective budget.

The range of temporal resolution of data is also wide. Available data result from (i) episodic events such as Saharan dust storms (few days per year or less) which represent roughly $50 \%$ of the external input of atmospheric particles, (ii) daily to monthly data, such as the environmental monitoring in WWTP, (iii) monthly data (such as custom registers) and (iv) annual data (economical statistics). Occasional $24 \mathrm{~h}$ surveys (once or twice a year) of industrial waste waters release in rivers were also used.

River exports at mouth, commonly determined on an annual basis, encapsulate the whole catchment information, i.e. natural fluxes, leaks from the anthroposphere and 


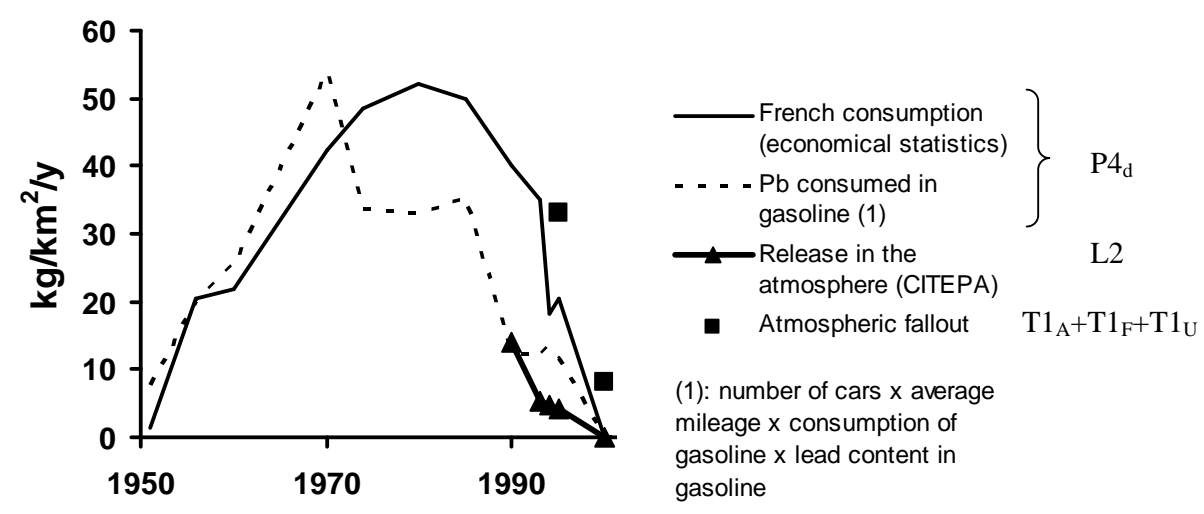

Fig. 3. Long term trend of leaded gasoline in atmosphere (flows/fluxes in $\mathrm{kg} / \mathrm{km}^{2} / \mathrm{y}$ ) (see legend of Fig. 2).

retention processes within aquatic system. In our averaged 10 year budget (Thévenot et al., 2007), monthly and/or seasonal surveys were upscaled at the annual level. Some fluxes (e.g. River outputs T4, Fig. 1, Table 2) were averaged over the 1990-2000 period, to smooth the annual variation of river metal contamination (Gromaire et al., 2002; Grosbois et al, 2006; Meybeck et al., 2007), which results from the following events: (i) during major storm events Paris sewers overflow into the river, resulting in spikes of suspended matter contamination within the Parisian reach; (ii) during high water periods metal contents may vary with tributary mixing and re-suspension of deposited sediments; (iii) year to year variations of average metal contents in suspended particulate matter (SPM) are linked to the average river discharge with higher values observed during dry years; (iv) on the contrary the river fluxes of metal are directly linked to suspended matter fluxes, always higher during wet years. The sediment transport during floods is not relevant here since we are considering 5y averages based on bimonthly SPM analyses and daily suspended sediment fluxes at river mouth and/or annual flood deposits which are representative of high flow periods (Horowitz et al., 1999). Other fluxes were known for few years only and had to be extrapolated to the whole period.

\subsection{Critical analysis of selected data sources}

Each type of material flow should be characterized by its period of record, its space scale (generally at the country level), its uncertainty, and its availability. Upscaling/downscaling issues and miscellaneous time scales lead to diverse data uncertainties and limitations, which are here qualitatively estimated (Table 4).

As an example, the metal atmospheric fallout $\mathrm{T} 1$ was determined by aggregating several sources of data, followed by data upscaling. It is noteworthy that only few academic studies of atmospheric fallout of metals are available in France. There is no fallout network, therefore the 5-year survey of terrestrial mosses contamination is considered (Gombert et al., 2004). Its sampling point's grid is $30 \times 30 \mathrm{~km}$ in accor- dance to the European guidelines for moss sampling sites. Several hundred stations of moss contamination for $\mathrm{Cd}, \mathrm{Cu}$, $\mathrm{Pb}, \mathrm{Ni}$ and $\mathrm{Zn}$ were used. A multi-metal index of moss contamination was then generated and spatially distributed in the Seine river catchment, allowing for the determination of four zones of moss contamination levels with their respective area. Pilot studies of atmospheric fallout were conducted at six stations located in these different zones, assuming a direct relation between metal fallout and moss contamination, resulting in specific areal weights for each fallout station. The Seine basin fallout is then computed on the basis of station fallout figures $\left(\mathrm{kg} \mathrm{km}^{-2} \mathrm{y}^{-1}\right)$ and their respective weights.

Another example of three different approaches is shown in Fig. 3: the long term trend (1950-2000) of atmospheric lead contamination is estimated from both economic and environmental data. Atmospheric lead is mainly due to leaded gasoline. Its flows $\left(\mathrm{P} 4_{d}\right)$ since the 1950's can be estimated (i) from economical statistics (INSEE) of leaded gasoline products here downscaled to the Seine basin limits, (ii) from car traffic records times gas consumption, taking into account the evolution of lead content in French gasoline since the 1970's, which decreases from $1.3 \mathrm{~g} / \mathrm{l}$ of tetraethyl lead $\left(\mathrm{PbEt}_{4}\right)$ before 1975 to 0.40 between 1975 and 1991, to 0.15 after 1991, before been banned in 2000 (various sources; INSEE, 2002), (iii) direct emissions (L2 of Fig. 2) of lead metal to the atmosphere as published at the county scale since 1990, which only covers the very last part of the atmospheric lead story (CITEPA, 2004), and (iv) annual lead fallout data as calculated from moss contamination and direct fallout measurements at six stations $\left(\mathrm{T}_{\mathrm{F}}+\mathrm{T} 1_{\mathrm{A}}+\mathrm{T} 1_{\mathrm{U}}\right)$. Although the recent decrease of $\mathrm{Pb}$ emission and fallout is well established in the four approaches, absolute numbers may be different up to a factor 8, in 1995 .

The Table 4 is a first attempt to take into account these difficulties of F2A: the general heterogeneity of these various sources of information is striking, yet they can be merged into general budgets, comparison of fluxes and flows and trend analysis. 
Table 4. Limitations of selected data sources for Flux-Flow Analysis (Fig. 2).

\begin{tabular}{|c|c|c|c|c|c|c|c|c|}
\hline & Flows and fluxes & $\begin{array}{l}\text { Space } \\
\text { coverage (1) }\end{array}$ & $\begin{array}{l}\text { Record } \\
\text { frequency (2) }\end{array}$ & $\begin{array}{l}\text { Space } \\
\text { treatment (3) }\end{array}$ & $\begin{array}{l}\text { Time } \\
\text { treatment (4) }\end{array}$ & $\begin{array}{l}\text { Data } \\
\text { accessibility (5) }\end{array}$ & $\begin{array}{l}\text { Data } \\
\text { uncertainties (6) }\end{array}$ & Remarks \\
\hline $\mathrm{P} 1, \mathrm{P} 2$ & $\begin{array}{l}\text { Imports of metals and } \\
\text { goods }\end{array}$ & $\mathrm{N}$ & $\mathrm{Y}$ & 3 & - & I to II & $\mathrm{L}$ & $\begin{array}{l}\text { Needs to be disaggregated } \\
\text { for each type of good }\end{array}$ \\
\hline $\mathrm{P} 4 \mathrm{a}$ & Lead in TV set & $\mathrm{N}$ & M & 2,3 & $\mathrm{D}$ & $\mathrm{V}$ & M & $\begin{array}{l}\text { Needs primary sources } \\
\text { combination }\end{array}$ \\
\hline P4d & Leaded gasoline & $\mathrm{N}$ & $\mathrm{Y}$ & 2,3 & - & II or V & $\mathrm{L}$ to $\mathrm{M}$ & \\
\hline P5 & Recycled goods & $\mathrm{N}$ & M & 3 & $\mathrm{D}$ & $\mathrm{I}, \mathrm{V}$ & $\mathrm{M}$ to $\mathrm{H}$ & \\
\hline $\mathrm{P} 8_{B}$ & Sewage sludge & I & $\mathrm{Y}$ & 1 & - & III & $\mathrm{L}$ & Needs to be better localized \\
\hline P10 & Dredged material & $\mathrm{B}$ & M & - & $\mathrm{A}, \mathrm{B}$ & III & M & Needs to be better localized \\
\hline $\mathrm{T} 1$ & Atmospheric fallout & $\mathrm{S}$ & S & 1 & $\mathrm{~A}, \mathrm{~B}$ & IV & $\mathrm{L}$ & Very limited space cover \\
\hline $\mathrm{T} 2 \mathrm{~F}$ & Background level & B & - & - & - & IV & $\mathrm{L}$ & \\
\hline $\mathrm{T} 3, \mathrm{~T} 4$ & Upper river fluxes & $\mathrm{B}$ & $S$ & - & A & I & $\mathrm{L}$ to $\mathrm{M}$ & \\
\hline $\mathrm{L} 1, \mathrm{~L} 2$ & $\begin{array}{l}\text { Atmospheric emissions } \\
\text { (CITEPA) }\end{array}$ & $\mathrm{C}, \mathrm{N}$ & Y & 3,4 & - & I & $\mathrm{H}$ to $\mathrm{VH}$ & $\begin{array}{l}\text { Based on nominal emission } \\
\text { rates }\end{array}$ \\
\hline L1 & $\begin{array}{l}\text { Atmospheric emission } \\
\text { (EPER) }\end{array}$ & I & $\mathrm{Y}$ & 4 & - & I & $\mathrm{M}$ to $\mathrm{H}$ & $\begin{array}{l}\text { Improve frequency: possi- } \\
\text { ble bias in survey }\end{array}$ \\
\hline${ }^{\mathrm{L}} 3_{\mathrm{A}}, \mathrm{L} 5$ & $\begin{array}{l}\text { Industrial wastes waters } \\
(\mathrm{AESN})\end{array}$ & I & $\mathrm{Y}$ & 4 & B & II & $\mathrm{L}$ & $\begin{array}{l}\text { Autocontrols mixed with } \\
\text { random analyses (lost } \\
\text { records) }\end{array}$ \\
\hline L6 & $\begin{array}{l}\text { Urban wastewaters } \\
\text { (SIAAP) }\end{array}$ & I & $\mathrm{Y}$ & 4 & - & III & $\mathrm{L}$ & $\begin{array}{l}\text { SIAAP survey protocol to } \\
\text { be generalized on basin }\end{array}$ \\
\hline SA & Agricultural soil storage & $\mathrm{C}$ & $\mathrm{L}$ & - & $\mathrm{C}$ & I to III & $\mathrm{L}$ & $\begin{array}{l}\text { Database accessibility lim- } \\
\text { ited }\end{array}$ \\
\hline SL & Landfill storage & $\mathrm{I}, \mathrm{C}$ & $\mathrm{L}$ & 2,4 & $\mathrm{C}$ & II to III & $\mathrm{H}$ & $\begin{array}{l}\text { Need for specific invento- } \\
\text { ries }\end{array}$ \\
\hline SU & Storage in structures & I & $\mathrm{L}$ & 2,4 & $\mathrm{C}$ & IV & $\mathrm{H}$ to $\mathrm{VH}$ & Very limited information \\
\hline R4 & $\begin{array}{l}\text { Long term sediment } \\
\text { archives }\end{array}$ & B & - & - & - & IV & $\mathrm{L}$ to $\mathrm{M}$ & $\begin{array}{l}\text { Needs to be completed on } \\
\text { subbasins }\end{array}$ \\
\hline
\end{tabular}

(1) Space coverage. N: national, B: basin and subbasins, C: county, S: station survey, I: individual (e.g. For each industry or city)

(2) Record frequency. Y: yearly, M: multiannual, S: seasonal to monthly, L: long term

(3) Space treatment. Type 1: need for upscaling since data are available on very small territories, Type 2: need for downscaling (data available at very large territory), Type 3: need for boundaries adjustment (administration census different from hydrological limits), Type 4: need for completeness (missing data in inventories).

(4) Temporal treatment. Type A: need for temporal extrapolation (data available over short periods only), Type B: need for temporal interpolation (fragmented data), Type C: need for cumulated fluxes and stocks, Type D: need for gradual evolution (instead of stepwise).

(5) Data accessibility. Type I: downloadable computerized data, Type II: accessible non-computerized data, Type III: restricted access data (exchangeable, person to person connexion etc.), Type IV: academic study without accessible database, Type V: combination of different sources with variable access.

(6) Data uncertainties. VH (very high): order of magnitude only, H (high): $>50 \%, \mathrm{M}$ (medium): $20 \%-50 \%, \mathrm{~L}$ (low): $<20 \%$

\section{Application of the F2A approach to the metal circula- tion in the Seine catchment}

The Flux-Flow Analysis, despite its difficulties and uncertainties, can be performed at the river basin scale. It is presented here for the zinc budget (1994-2003), comparing of fluxes and flows, and for the long term trends of fluxes and flows through two specific indicators.

\subsection{The average zinc budget (1994-2003)}

The annual Zn budget has been assessed in the Seine River basin, for the 1994-2003 period, using the sets of data previously described in Thévenot et al. (2007) (Fig. 4). More than two dozens of fluxes have been measured or estimated and ranked. They all refer to a catchment area of $65000 \mathrm{~km}^{2}$. Atmospheric deposits reach 500 and $600 \mathrm{ty}^{-1}$ on forestsgrassland and on cultivated land respectively. These $\mathrm{Zn}$ inputs to soils $\left(\mathrm{T} 1_{\mathrm{A}}+\mathrm{T}_{\mathrm{F}}: 1100 \mathrm{ty}^{-1}\right)$ are much larger than those related to the use of fertilisers (P7: $30 \mathrm{ty}^{-1}$ ) and to the recycling of waste water treatment plant sludge (P8: $80 \mathrm{ty}^{-1}$ ). They are only overpassed by waste disposal in waste dumps (urban solid waste and collected sand from domestic sewer settling chambers, P9: $1700 \mathrm{ty}^{-1}$; and a fraction of waste water treatment plant sludge, $\mathrm{P} 8_{\mathrm{A}}$ : $\left.180 \mathrm{ty}^{-1}\right)$. The circulation of $\mathrm{Zn}$ in the anthroposphere is thus, hopefully, much higher than direct inputs to rivers: anthropogenic leaks in rural area are estimated as $5 \mathrm{t} \mathrm{y}^{-1}(\mathrm{~T} 2 \mathrm{~A})$. They are negligible when compared to industrial direct inputs (L5: $35 \mathrm{ty}^{-1}$ ) and to urban area inputs: sewer overflows (L6: $80 \mathrm{ty}^{-1}$ ) and waste water treatment plant outlet (L4: $\left.130 \mathrm{ty}^{-1}\right)$. If these direct inputs to rivers $\left(250 \mathrm{ty}^{-1}\right)$ are added to the upstream river basin erosion (T3: $42 \mathrm{ty}^{-1}$ ) and corrected by particulate retention in reservoirs (SR1: $\left.0.7 \mathrm{ty}^{-1}\right)$, alluvial plains (SR2: $2.5 \mathrm{ty}^{-1}$ ) or related to sediment dredging for river navigation maintenance (P10: $14 \mathrm{ty}^{-1}$ ), one should expect a total output of $275 \mathrm{ty}^{-1}$ at the river mouth at Poses. The difference with the measured value (T4: $450 \mathrm{ty}^{-1}$ i.e. $315 \mathrm{ty}^{-1}$ for particulate $\mathrm{Zn}+135 \mathrm{ty}^{-1}$ for dissolved $\mathrm{Zn}$ ) shows clearly that some significant inputs to river have not been accounted for. It is likely that such inputs result from unaccounted leaks from urban and industrial storage sites. 


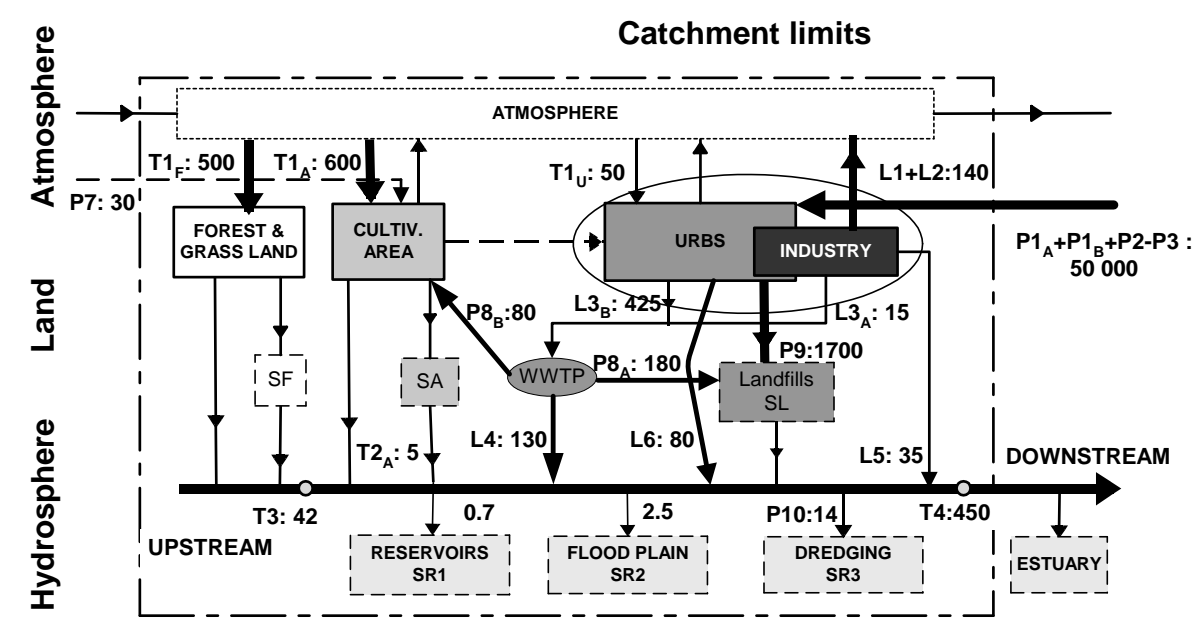

Fig. 4. Zinc budget in the Seine basin : mean fluxes and flows during the 1994-2003 period ( $\mathrm{t}^{-1}$ ) (data from Thévenot et al., 2007).

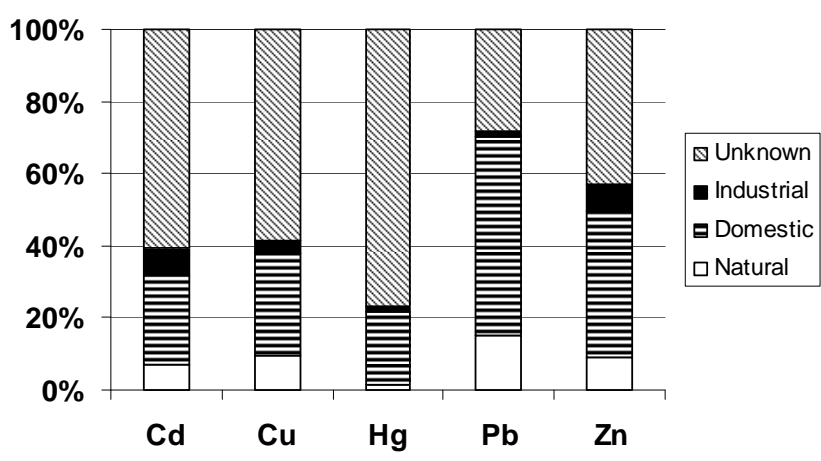

Fig. 5. Percentage of $\mathrm{Cd}, \mathrm{Cu}, \mathrm{Hg}, \mathrm{Pb}, \mathrm{Zn}$ sources in total export at the river mouth station Poses: (i) release from erosion ("natural"), (ii) calculated domestic release ("domestic") and (iii) directly measured or declared direct release of industrial waste water into rivers ("industrial"), (iv) unknown sources.

\subsection{Comparison of Fluxes and Flows approaches}

Two types of comparison have been made: first on atmospheric emissions and fallout; then on the anthropogenic output versus total output at the river mouth. Industrial and urban emissions (Flows, including estimated emissions from transport) vs. measured fallout (Fluxes) are estimated separately in most studies. As shown by Thévenot et al. (2007), who compared these two estimates for seven metals, agreement between emissions and excess fallout (corrected from aeolian erosion) are generally good, fallout being between 0.8 and 10 times the emissions figures.

In Fig. 5, the total metal output at the river mouth is compared to (i) natural sources (soil erosion), (ii) domestic inputs based on river surveys and (iii) industrial sewage release to rivers. The contribution of soil erosion was calculated on the basis of an average river SPM yield of $10.8 \mathrm{t} \mathrm{km}^{-2} \mathrm{y}^{-1}$ and a basin average metal content for pristine SPM. "Domestic" inputs were calculated from metal fluxes at selected river stations $(n=15)$, upstream and down stream Paris, for population density ranging from 20 to $800 \mathrm{inhab} / \mathrm{km}^{2}$. These fluxes were found to be proportional to the population density for most stations. These fluxes were then prorated to the population, determining a "domestic" per capita release expressed in $g$ per capita per year, of which the median is considered and then extrapolated to the whole catchment. The industrial sources result both from voluntary industrial declaration procedure and from partially measured and extrapolated fluxes (see Table 3, L5 calculated or measured by different ways). Details and estimated uncertainties ranges are given in Thévenot et al. (2007). The difference between the sum of natural, domestic and industrial sources and the measured total metal output represents the "unknown output", ranging from $83 \%$ of the total output for $\mathrm{Hg}$ to $30 \%$ for $\mathrm{Pb}$. This large percentage of "unknown sources" illustrates the interest of comparing fluxes and flows: such discrepancy between measured values and determined outputs reveals the lack of knowledge about data uncertainties and some metal contamination sources. We suspect that reported industrial sources are underestimated: surveys are much less frequent and/or representative of total annual releases than river survey. Unaccounted leaks from past metal storage sites as industrial sites (SI) and landfills (SL) must also be considered. Long term storage in soils and sediments, in waste dumps and urban structures represents an important retention on continents, which is a major feature of the Earth system functioning (Meybeck and Vorosmarty, 2005). This heritage of more than $200 \mathrm{yrs}$ of metal industries in the catchment should now be investigated. Another long term heritage of human activity is the acute contamination of $\mathrm{Zn}, \mathrm{Cd}$ and other metal in a restricted area of about $30 \mathrm{~km}^{2}$ west of Paris where the city waste waters have been used for farmland irrigation since the 1890's (Barles, 1999). 

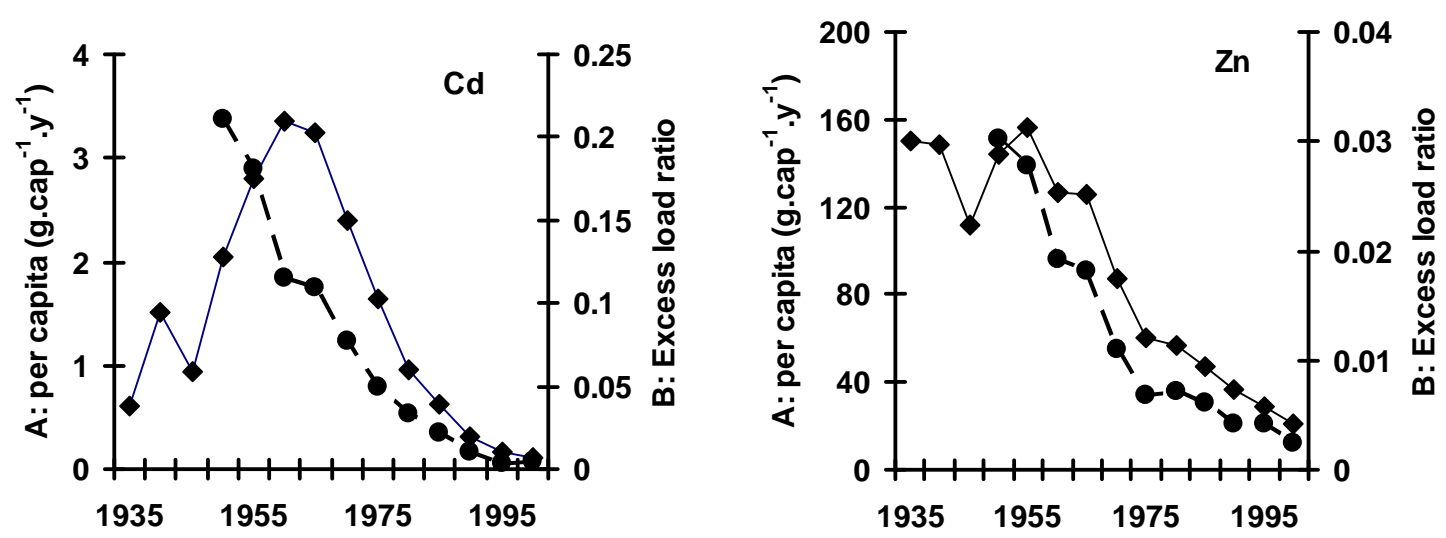

Fig. 6. Integrated F2A indicators for $\mathrm{Cd}$ (left) and $\mathrm{Zn}$ (right). A ( $)$ : Annual average river excess metal load prorated to the Seine basin population $\left(\mathrm{g} \mathrm{cap}^{-1} \mathrm{y}^{-1}\right)$. B (•): Annual export by the river/total metal demand in the catchment (leakage ratio) (data from Meybeck et al., 2007).

\subsection{Integrated F2A indicators}

The combination of flows and fluxes indicators allows for proposing two integrated indicators that describe the evolution of metal circulation over a period of $50 \mathrm{yrs}$ (Meybeck et al., 2007): (i) the per capita excess load of metals corresponds to the estimated metal load in river particulates that adds to natural erosion and is present at the river mouth; it is averaged here over a period of 5 years and expressed as $g$ metal per capita per year; (ii) the leakage ratio over the river catchment, i.e. the ratio of excess metal flux at the river outlet divided by the general metal use within the catchment, also averaged over periods of 5 years. These indicators are here illustrated for cadmium and zinc (Fig. 6).

The per capita excess loads of metal have been determined at the river mouth station. The metal contamination survey carried on suspended matter since 1983 has been used to validate the metal contamination archived in floodplain cores for the 1935-2000 period at the same site. A constant sediment flux of $700000 \mathrm{t} / \mathrm{year}$ is then associated to metal contents to generate average fluxes for $5 \mathrm{y}$ periods. Grain-size corrections, dissolved metals correction, background references and population evolution are detailed in Meybeck et al. (2007). The excess loads depend on metals and periods as illustrated for zinc and cadmium (Fig. 6). For zinc an increase of the excess load is observed from 1935 to 1955, with a notch in 1940-1945 that can be attributed to the impact of World War II on the general industrial activity. Since 1955 there is an 8-fold decrease of excess zinc per capita from 150 to $21 \mathrm{~g} \mathrm{Zn} \mathrm{cap}^{-1} \mathrm{y}^{-1}$. For cadmium, there is a well-marked maximum in 1960-1965, then a 30 -fold decrease from 3.35 to $0.10 \mathrm{~g} \mathrm{Cd} \mathrm{cap}^{-1} \mathrm{y}^{-1}$. These values are close to those established for Stockholm in 1999 by Sörme and Lagerkvist (2002) (Zn: $16.3 \mathrm{~g} \mathrm{cap}^{-1} \mathrm{y}^{-1}$ and Cd: $0.04 \mathrm{~g} \mathrm{cap}^{-1} \mathrm{y}^{-1}$ ). Other metals $(\mathrm{Pb}, \mathrm{Cu}, \mathrm{Cr}$ and $\mathrm{Hg}$ ) trajectories confirm a major decrease of contamination in the last 50 years.
The second indicator rates the excess fluxes exported by the river basin, averaged for $5 \mathrm{yr}$ periods. The metals flows from 1950 to 2000 have several patterns (Meybeck et al., 2007): (i) general increase by a factor 2.5 to 5 for $\mathrm{Cu}, \mathrm{Cr}$, $\mathrm{P}$ and $\mathrm{Zn}$, (ii) general decrease since 1960 by more than 10 for $\mathrm{Hg}$ and (iii) a recent decrease by $40 \%$ of the $\mathrm{Cd}$ demand since 1995 . The leakage ratio of all metals is markedly decreasing: in 1960 it exceeded more than $20 \%$ for $\mathrm{Cd}$ and was an order of magnitude less for $\mathrm{Zn}$. Now it has decreased by an order of magnitude for both metals. (Fig. 6).

Only the comparison of fluxes (metal export by the river) and flows (metal demand on the catchment) could lead to such trend analysis: despite the increasing population (50\%) and increasing use of metal per capita, the metal decontamination is really effective. This is attributed to the early deindustrialization of the catchment since 1960, particularly Paris megacity and to the recycling of metals in the industrial sector (Thévenot et al., 2007; Meybeck et al, 2007).

4.4 General decline of metal contamination in Europe: need for F2A

Although the metal contamination trend in river systems is station-specific and metal-specific, there is a general decontamination observed in European rivers exposed to multiple human impacts. The $\mathrm{Zn}$ evolution in deposited fine alluvial sediments near the river mouth of several rivers is shown in Fig. 7. The profile of contamination has been reconstructed from several sources: Middlekoop (1997) for the Rhine, Harland et al. (2000) for the Mersey downstream of Liverpool, Winkels et al. (1998) for the Danube and Volga, Zwolsman and van Eck (1999) for the Scheldt downstream of Anvers, Grousset et al. (1999) for the Garonne at Bordeaux. The Seine River is always among the most contaminated rivers over the period of record (1935-2000). The background Zn level is very similar in most rivers, about $80 \pm 20 \mu \mathrm{g} \mathrm{g}^{-1}$, a 


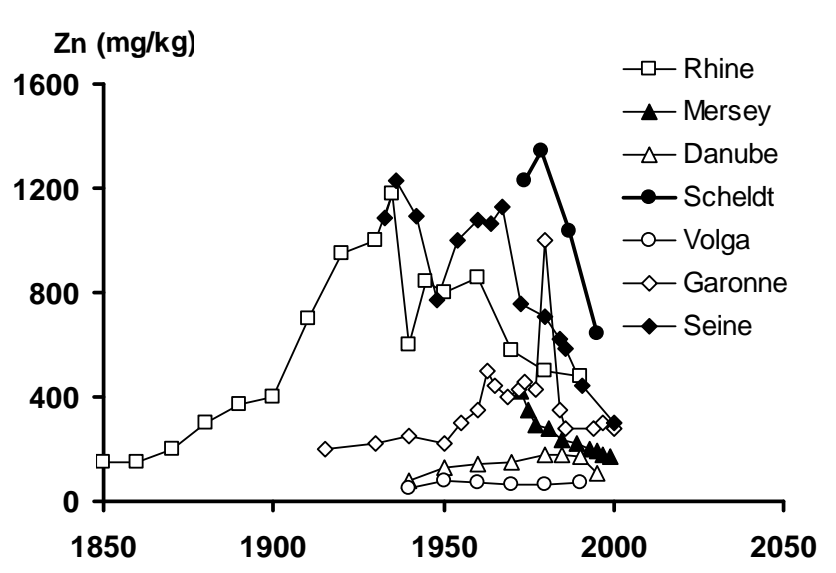

Fig. 7. Comparison of $\mathrm{Zn}$ contamination trends in seven rivers from the analysis of river flood plain sediments near river mouth (mg Zn/kg sediment).

value still observed for the Volga and largely exceeded for all other rivers. The maximum decontamination rates are observed for the most contaminated rivers, Seine and Rhine, after the 1930-1960 peak, incised by the World War II notch. These general trends correspond to a combination of multiple sources both urban and industrial. For the Garonne River, a marked peak is noted in 1980, probably due to a short-term industrial or mining source. A detailed Flux-Flow Analysis should now be made on all these river systems, in order to quantify the metal sources, determine their drivers and the human response to contamination, if any, as attempted by Meybeck et al. (2007). The F2A approach is a precious tool in the DPSIR analysis recommended by the EU Water Framework Directive.

\section{Conclusions}

Global changes for contaminants as heavy metals should be based on local to regional studies (Steffen et al., 2004). The F2A is an adequate tool for better understanding the circulation of contaminants at such scales. It is based on multiple and heterogeneous sources of data which are generated at different space and time scales, and have variable data quality insurance. Actually many data on waste release have no quality insurance comparable to those found in environmental studies, from field sampling and laboratory analyses to flux determinations (Rode and Suhr, 2007). One should think now to generate and focus the economic data considering their eventual use as data sources for environmental budgets.

Despite these uncertainties the F2A can lead to a coherent description of metal circulation. The river catchment is a natural unit for such analysis provided that its size allows for the downscaling of many economic statistics that are only known at the national level. The detailed budget analysis allows ranking of the major fluxes and flows. In the Seine catchment, it is clear that metal flows in the anthroposphere are now one to two orders of magnitude greater than present metal leaks to the environment, either to the atmosphere or to the aquatic system. The catchment budget also reveals several types of long term storage in soils and sediments and in waste dumps and urban structures. However, it seems difficult to realize such budget for another period, e.g. at the peak of contamination in 1955-1960, for lack of detailed fluxes and flows.

The per capita excess loads and the leakage ratio are robust indicators which describe the overall metal circulation in the system and can be generated from country statistics and sediment archives. The trend analysis should now be compared to other well-documented catchments as the Rhine, Elbe, Scheldt or Humber, in order to check if the efficiency of the anthroposystem in avoiding the leakage of its metals has also been greatly improved over the last 50 years.

Acknowledgements. This paper is part of the PIREN-Seine Programme (1989-2005) which benefited from the financial support of a dozen public and private institutions backed by the Agence de l'Eau Seine-Normandie (AESN). We greatly acknowledge all of them. The help of several laboratories (Unite de Science du Sol (INRA), Laboratoire des Sciences du Climat et de l'Environnement (LSCE), Laboratoire Interuniversitaire des Systèmes atmosphériques (LISA)) has been much appreciated.

Edited by: A. Ducharne

\section{References}

AESN: Priority pollutant released by industries upstream the Seine River mouth: first results of the 2005-2006 campaign, AESN, Nanterre, 2006.

Azimi, S., Ludwig, A., Thévenot, D. R., and Colin, J. L.: Trace metal determination in total atmospheric deposition in rural and urban areas, Sci. Total Environ., 308, 247-256, 2003.

Azimi, S., Rocher, V., Garnaud, S., Varrault, G., and Thévenot, D.: Decrease of atmospheric deposition of heavy metals in an urban area from 1994 to 2002 (Paris, France), Chemosphere, 61, 645651, 2005.

Baccini, P. and Brunner, P. H.: Metabolism of the Anthroposphere, Springer-Verlag, Berlin, 1991.

Barles, S.: La ville délétère, Champ Vallon, Seyssel, 1999.

Bergbäck, B., Johansson, K., and Molhander, U.: Urban metal flows - a case study of Stockholm, Review and Conclusions, Water Air Soil Pollut. Focus, 1(3-4), 3-24, 2001.

Billen, G., Toussaint, F., Peters, P., Sapir, M., Steenhout, A., and Vanderborght, J. P: L'écosystème Belgique, Essai d'écologie industrielle, CRISP, Bruxelles, 163 pp., 1983.

Billen, G., Garnier, J., Némery, J., Sebilo, M., Sferratore, A., Barles, S., Benoit, P., and Benoît, M.: A long-term view of nutrient transfers through the Seine river continuum, Sci. Total Environ., 375, 80-97, 2007.

Brunner, P. H. and Rechberger, H.: Practical Handbook of Material Flow Analysis, Lewis Publishers, New York, 2004. 
Cave, R. R., Ledoux, L., Turner, K., Jickells, T., Andrews, J. E., and Davies, H.: The Humber catchment and its coastal area: from UK to European perspectives, Sci. Total Environ., 314-316, 3152, 2003.

Ciais, P., Borges, A. V., Abril, G., Meybeck, M., Folberth, G., Hauglustaine, D., and Janssens, I. A.: The impact of lateral carbon fluxes on the European carbon balance, Biogeosciences Discuss., 3, 1529-1559, 2006, http://www.biogeosciences-discuss.net/3/1529/2006/.

CITEPA: Calcul des émissions dans l'air, Principes méthologiques généraux, www.citepa.org, CITEPA, Paris, 2004.

EEA: Corine Land Cover, http://dataservice.eea.eu.int/dataservice, European Environment Agency, Copenhagen, 2000.

EauFrance: Rejets industriels, 1998 to 2002 data, www.eaufrance. fr, Ministère de l'Ecologie et du Développement Durable, Paris, 2004.

FEDEM (Fédération des métaux non ferreux): L'industrie des minerais, minéraux industriels et métaux non ferreux, Chiffres clés 2002, FEDEM, Paris, 2003.

Garnaud, S., Mouchel, J. M., Chebbo, G., and Thévenot, D.: Heavy metal concentrations in dry and wet atmospheric deposits in Paris district: comparison with urban runoff, Sci. Total Environ., 235, 235-245, 1999.

Gombert, S., Rausch de Traubenberg, C., Losno, R., Leblond, S., Colin, J. L., and Cossa, D.: Biomonitoring of element deposition using mosses, in the 2000 French survey: identifying sources and spatial trends, J. Atmos. Chem., 49, 479-502, 2004.

Graedel, T. E. and Allendy, B. R.: Industrial Ecology, 2nd edition, Prentice Hall, Pearson Education Inc., Upper Saddle River, New Jersey, 2003.

Gromaire, M. C., Chebbo, G., and Constant, A.: Impact of zinc roofing on urban runoff pollutant loads: the case of Paris, Water Sci. Technol., 45(7), 113-122, 2002.

Grosbois, C., Meybeck, M., Horowitz, A., and Ficht, A.: The spatial and temporal trends of $\mathrm{Cd}, \mathrm{Cu}, \mathrm{Hg}, \mathrm{Pb}$ and $\mathrm{Zn}$ in Seine River floodplain deposits (1994-2000), Sci. Total Environ., 356, 2237, 2006.

Grousset, F. E., Jouanneau, J. M., Castaing, P., Lavaux, G., and Latouche, C.: A 70 year record of contamination from industrial activity along the Garonne River and its tributaries (SW France), Estuarine, Coastal and Shelf Sci., 48, 401-414, 1999.

Harland, J., Taylor, D., and Wither, A.: The distribution of mercury and other trace metals in the sediments of the Mersey estuary over 25 years, 1974-1998, Sci. Total Environ., 253, 45-62, 2000.

Horowitz, A. J.: A primer on sediment-trace element chemistry, 2nd ed., Lewis publishers Inc, Chelsea, MI, 1991.

Horowitz, A. J., Meybeck, M., Idlafkih, Z., and Biger, E.: Variations in trace element geochemistry in the Seine River Basin based on floodplain deposits and bed sediments, Hydrol. Processes, 13, 1329-40, 1999.

INSEE: 2000 Annual report, Institut National de la Statistique et des Etudes Economiques, Paris, 2002.
IREP: Registre Français des Emissions Polluantes, 2004, http/ //www.pollutionsindustrielles.ecologie.gouv.fr/IREP/, Ministère de l'Ecologie et du Développement Durable, Paris, 2004.

Meybeck, M., Lestel, L., Bonté, P., Moilleron, R., Colin, J. L., Rousselot, O., Hervé, D., de Pontevès, C., Grosbois, C., and Thévenot, D. R.: Historical perspective of heavy metals $(\mathrm{Cd}, \mathrm{Cr}$, $\mathrm{Cu}, \mathrm{Hg}, \mathrm{Pb}, \mathrm{Zn}$ ) in the Seine river basin (France) following a DPSIR approach (1950-2005), Sci. Total Environ., 375, 204-231, 2007.

Meybeck, M. and Vorosmarty, C.: Fluvial filtering of land-to-ocean fluxes, in : from natural Holocene variations to Anthropocene, C. R. Geosciences, 337, 107-123, 2005.

Middlekoop, H.: Embanked floodplains in the Netherland, Nederlandsee geographische studies, Utrecht Univ. Press, 224 pp., 1997.

Rode, M. and Suhr, U.: Uncertainties in selected river water quality data, Hydrol. Earth Syst. Sci., 11, 863-874, 2007, http://www.hydrol-earth-syst-sci.net/11/863/2007/.

Salomons, W. and Forstner, U.: Metals in the Hydrocycle, Springer Verlag, New York, 1984.

Sörme, L. and Lagerkvist, R.: Sources of heavy metals in urban wastewater in Stockholm, Sci. Total Environ., 298, 131-145, 2002.

Steffen, W, Sanderson, A., Tyson, P. D., Jager, J., Matson, P. A., Moore, B., Oldfield, F., Richardson, K., Schellnhuber, H. J., Turner, B. L., and Wasson, R. J. (Eds.): Global change and The Earth System, Springer-Verlag, New York, 2004.

Stigliani, W. M., Jaffé, P. R., and Anderberg, S.: Heavy Metal Pollution in the Rhine Basin, Environ. Sci. Technol., 27, 786-793, 1993.

Thévenot, D. R., Moilleron, R, Lestel, L., Gromaire, M. C., Rocher, V., Cambier, P., Bonté, P., Colin, J. L., de Pontevès, C., and Meybeck, M.: Critical budget of metal sources and pathways in the Seine river basin (1994-2003) for $\mathrm{Cd}, \mathrm{Cr}, \mathrm{Cu}, \mathrm{Hg}, \mathrm{Ni}, \mathrm{Pb}$ and $\mathrm{Zn}$, Sci. Total Environ., 375, 180-203, 2007.

Trefry, J. H., Nelsen, T. A., Trocine, R. P., Metz, S., and Vetter, T. W.: Trace metal fluxes through the Mississippi River delta system, in: CIESM Report 186, Contaminant fluxes through the coastal zone, edited by: Kullenberg, G., Monaco, 277-288, 1986.

Unifa: Les livraisons de fertilisants en France, campagne 20032004, Les chiffres-clés 2005, www.unifa.fr, Union des industries de la fertilisation, Paris, 2005.

Winkels, H. J., Kroonenberg, S. B., Lychagin, M. Y., Marin, G., Rusakov, G. V., and Kasimov, N. S.: Geochronology of priority pollutants in sedimentation zones of the Volga and Danube delta in comparison with the Rhine delta, Appl. Geochem., 13, 581591, 1998.

Zwolsman, J. J. G. and van Eck, G. T. M.: Geochemistry of major elements and trace metals in suspended matter of the Scheldt estuary, southwest Netherlands, Marine Chem., 66, 91-111, 1999. 